\title{
Early malignant syphilis observed during infection and reinfection in the same patient
}

\author{
K. LEJMAN AND Z. STARZYCKI \\ From the Dermatological Clinic, Medical Academy, Kraków, Poland
}

SUMmARY Malignant syphilitic infections occurring in the same woman at an interval of 38 months is reported. The first infection was diagnosed as secondary papulopustular and ecthymatous syphilis. The reinfection was more severe, taking the form of secondary ulcerative syphilis with fever, general deterioration, and loss of weight. Numerous Treponema pallidum were present in the serum expressed from the papulopustular lesions during the first infection, but they were absent from the secretion expressed from the margins of the ulcerative syphilides during the reinfection. Many treponemes were present in the plasma cell infiltrates in histopathological sections of the biopsy specimens taken from the margin of the ulcers.

\section{Introduction}

The destructive, ulcerating, and necrotic syphilides in early syphilis, commonly called malignant syphilis, are rare nowadays, although lately there have been reports of them (Agache et al., 1970; Degos et al., 1970; Laugier et al., 1970; Lejman and Starzycki, 1972; Jarowinskij and Cholin, 1973; Buck, 1974; Petrozzi et al., 1974; Sehgal and Rege, 1974; Lomyskin and Lanne, 1975; Pariser, 1975).

We have, however, been unable to find any report concerning malignant syphilitic infection and reinfection in the same patient.

\section{Case report}

FIRST INFECTION

The patient, a 38-year-old woman, was admitted on 11 July 1969 with a generalised eruption present for at least two weeks. She complained of fever, headache, and photophobia of the left eye. She was a prostitute and admitted sexual contact with many partners, none of whose personal details was known to her.

\section{Clinical examination}

The patient was of normal build and moderately nourished. She was $1.66 \mathrm{~m}$ tall and weighed $52 \mathrm{~kg}$. The axillary temperature was $38 \cdot 2^{\circ} \mathrm{C}$, and the pulse rate was 96 beats a minute.

Address for reprints: Professor K. Lejman, Klinika Dermatologiczna AM, ul. Kopernika 17, 31-501 Krakow, Poland

Received for publication 14 November 1977
The eruption covered the surface of her body (except for the palms of her hands and soles of her feet) particularly the trunk, abdomen, and genitals. The lesions ranged from papulopustular to papulonecrotic, and many were covered with dark, adherent crusts (Fig. 1). After desquamation of the necrotic crusts scattered, small, ecthymatous lesions could be seen. All the lesions had an erythematous base. On the genitals many of the pustules were denuded and oozing (Fig. 2). There were no lesions of the oral mucosa or of the anal region. She had iridocyclitis of the left eye.

\section{Laboratory investigations}

Darkground examination of the serum from the pustular lesions on the genitals and forearms showed typical, numerous, motile $T$. pallidum. Haemoglobin was $11.2 \mathrm{~g} / \mathrm{dl}(11.2 \mathrm{~g} / 100 \mathrm{ml})$; erythrocyte sedimentation rate was $88 \mathrm{~mm}$ in 1 hour; and white blood count (WBC) was $6 \cdot 1 \times$ $10^{9} / 1\left(6.1 \times 10^{3} / \mathrm{mm}^{3}\right)$ with a normal differential count.

\section{Serological tests}

The Wassermann reaction (WR) was strongly positive; the Venereal Disease Research Laboratory (VDRL) test gave positive results at a titre 1:64; the $T$. pallidum immobilisation (TPI) test result was positive at $100 \%$ immobilisation; the result of the fluorescent treponemal antibody 200 (FTA-200) test was positive at a titre 1:24000; the fluorescent treponemal antibody absorption (FTA-ABS) test also gave positive results. 


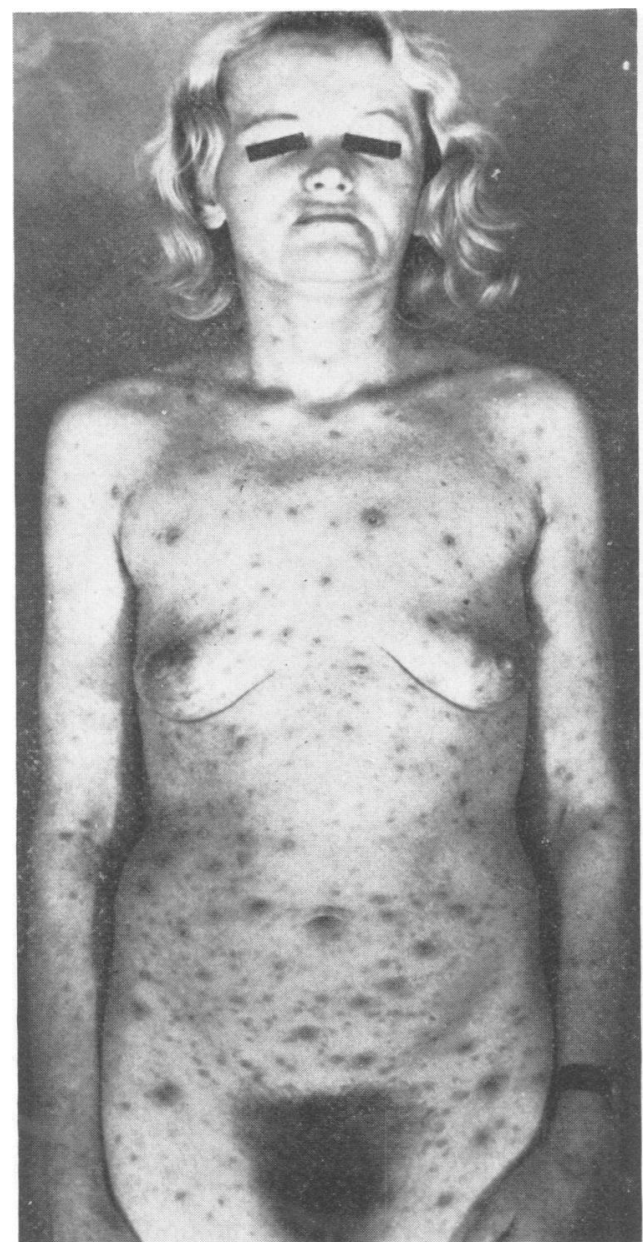

Fig. 1 Early secondary papulopustular and ecthymatous syphilides in the first infection.

\section{Lumbar puncture}

The cerebrospinal fluid (CSF) cell count was 3 cells $/ \mathrm{mm}^{3}$ and the protein was $0 \cdot 12 \mathrm{~g} / 1(12 \mathrm{mg} / 100$ $\mathrm{ml}$; the Pandy, Nonne-Apelt, and Weichbrodt tests gave negative results as did the WR, VDRL, and TPI tests; the FTA test was positive at a titre $1: 50$.

\section{Diagnosis}

Secondary malignant papulopustular and ecthymatous syphilis was diagnosed.

\section{Treatment and course of the illness}

The patient was given 600000 units procaine penicillin daily to a total of 21 megaunits. Seven hours after the first injection the body temperature

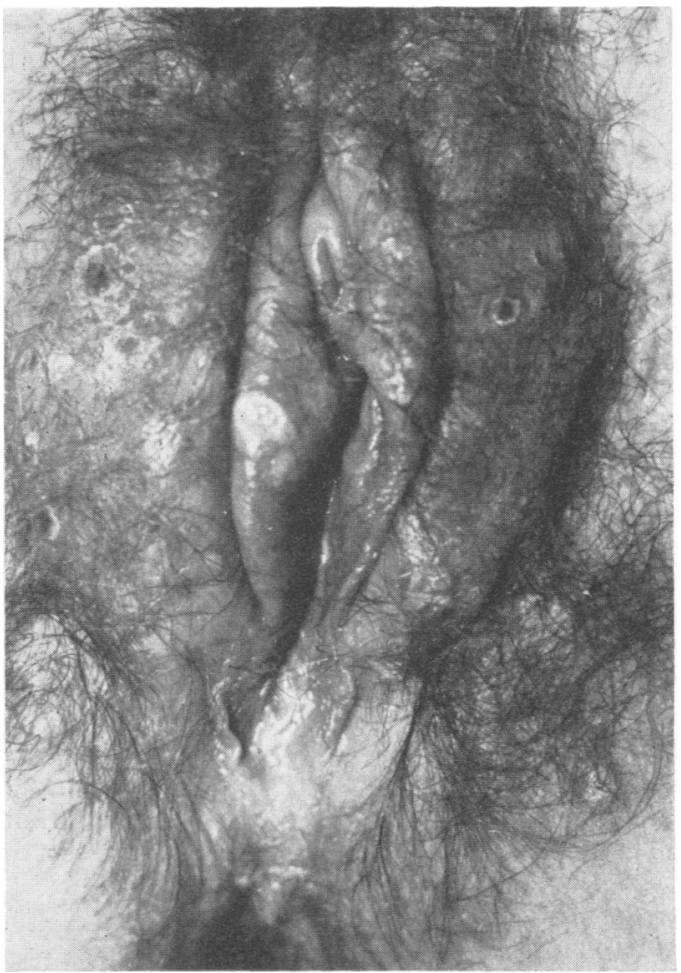

Fig. 2 Papulopustular syphilides on the genitals in the first infection.

rose to $40 \cdot 8^{\circ} \mathrm{C}$, returning to normal after 20 hours. The eruption healed slowly. The ophthalmological features disappeared completely.

On discharge from the clinic on 14 August the serological tests showed no change. The patient then moved her address and did not attend for follow-up examination. Fifteen months later, however, she attended the venereological dispensary, and the result of her VDRL test was negative.

\section{REINFECTION}

On 21 October 1972, 38 months after discharge from the clinic, the patient was again admitted with severe, ulcerating, partly necrotising, scattered cutaneous lesions.

She had noticed the onset of the lesions two months earlier, and since then had lost $8 \mathrm{~kg}$ in weight. The rash had been preceded by prodromal symptoms lasting one month-such as fever up to $38^{\circ}-39^{\circ} \mathrm{C}$, severe headaches, loss of appetite, and general weakness.

\section{Clinical examination}

She was undernourished; her weight was $48.5 \mathrm{~kg}$, and the axillary temperature was $37 \cdot 8 \mathrm{C}$. 
The lesions (11 in number) were spread on the extremities (Fig. 3), the right shoulder (Fig. 4), the neck, the interscapular region, and the right hip. The lesions were ulcerating and had polycyclic margins encircled with inflammatory borders and covered with necrotic crusts. Some of them, particularly those on the right shoulder, were composed of confluent ulcers resembling noduloulcerative tertiary syphilides. The lesions were slightly tender and secreted sticky, foul-smelling, colourless exudate.

\section{Laboratory investigations}

Repeated darkground examination of the exudate from the ulcers, as well as of the tissue fluid aspirated from the base, were negative for $T$. pallidum and sterile for fungi and Candida albicans. Staphylococcus aureus coagulase-positive, $\beta$ haemolytic Streptococcus pyogenes, and Corynebacterium pseudodiphtheriae were cultured from the ulcers.

Haemoglobin was $12 \cdot 1 \mathrm{~g} / \mathrm{dl}(12 \cdot 1 \mathrm{~g} / 100 \mathrm{ml})$; WBC was $8.4 \times 10^{9} / 1\left(8.4 \times 10^{3} / \mathrm{mm}^{3}\right)$ with normal differential count; and erythrocyte sedimentation rate was $97 \mathrm{~mm}$ in one hour.

\section{Serological tests}

The WR was strongly positive; the VDRL test gave positive results at a titre $1: 64$; the TPI test

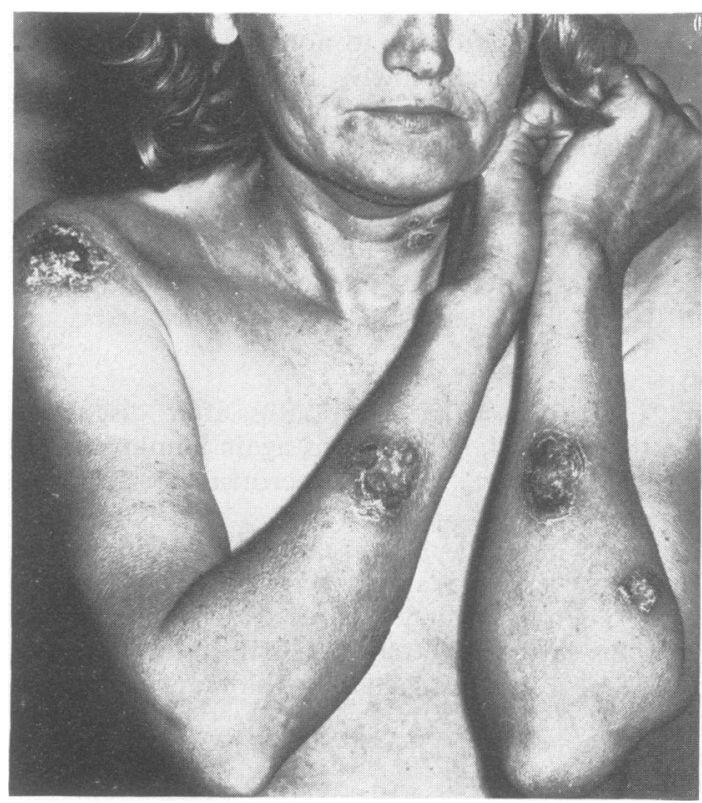

Fig. 3 Ulceronecrotic syphilides on the extremities in the reinfection.

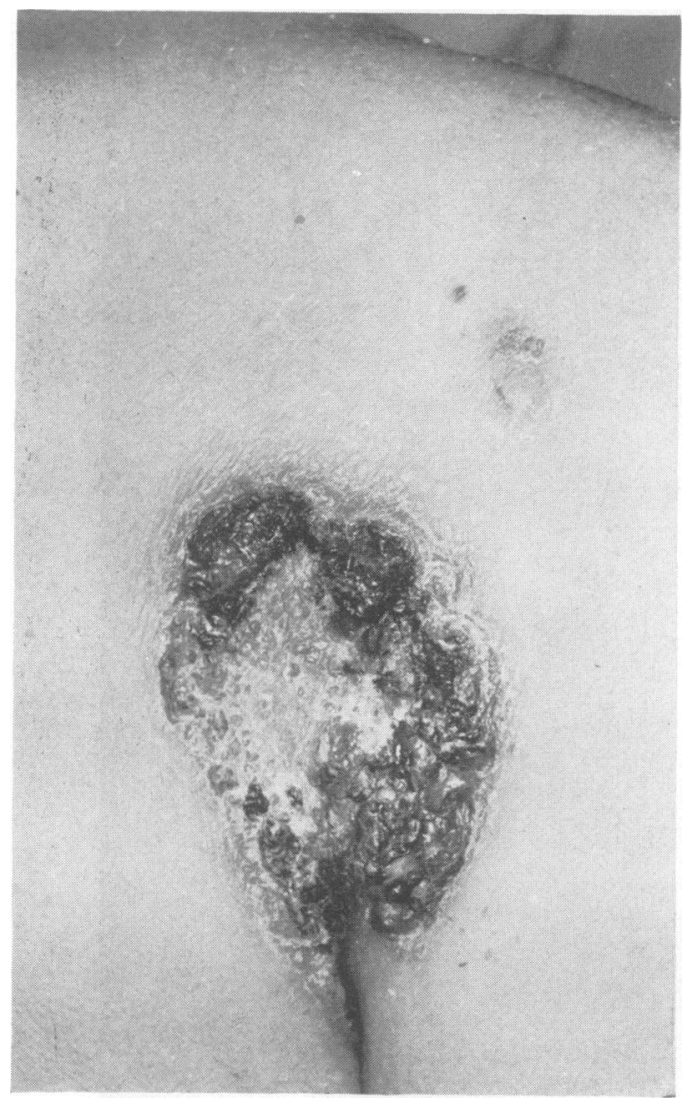

Fig. 4 Ulceronecrotic lesion similar to the tertiary syphilide on the right shoulder in the reinfection.

gave positive results with $100 \%$ immobilisation; and the FTA- ${ }_{200}$ test gave positive results at a titre $1: 4000$.

\section{Lumbar puncture}

The CSF cell count was 5 cells $/ \mathrm{mm}^{3}$; the protein was $0.26 \mathrm{~g} / \mathrm{l}(26 \mathrm{mg} / 100 \mathrm{ml})$; the Pándy, NonneApelt, and Weichbrodt tests gave results that were weakly positive. The WR and VDRL results were negative; the TPI result was positive with $100 \%$ immobilisation; and the FTA- ${ }_{200}$ result was positive at a titre 1:50.

\section{Histopathology}

Two biopsies from the margins of the lesions on the trunk and the hip were taken. Sections from both specimens were stained with haematoxylin and eosin and with modification of the Krajian silver impregnation method (Walter et al., 1969).

Sections stained with haematoxylin and eosin showed that the epidermis was hyperkeratotic and 
partly parakeratotic, and contained scattered intracorneal pustules. The malpighian rete was irregularly acanthotic, and the outline between epidermis and dermis was in places hazy. The capillary vessels of the papillary layer of the skin were greatly dilated and filled with blood. In the underlying layers of the skin the blood vessels were in places disrupted causing haemorrhages, and some of these were blocked by thrombi. The collagenous structure of the skin was almost completely distorted by a dense plasma cell infiltrate with a few lymphocytes and histiocytes (Fig. 5).

In the sections stained with modified Krajian's method masses of treponemes were present within the infiltrates of plasma cells (Fig. 6) as well as in the walls of the blood vessels and, in a few places, within the intravascular thrombi. The epidermis was free from treponemes.

\section{Diagnosis}

Reinfection in the form of early malignant, ulceronecrotic syphilis was diagnosed.

\section{Experimental investigations}

A healthy, seronegative (including WR, VDRL, TPI, FTA-200, and FTA-ABS tests) rabbit was

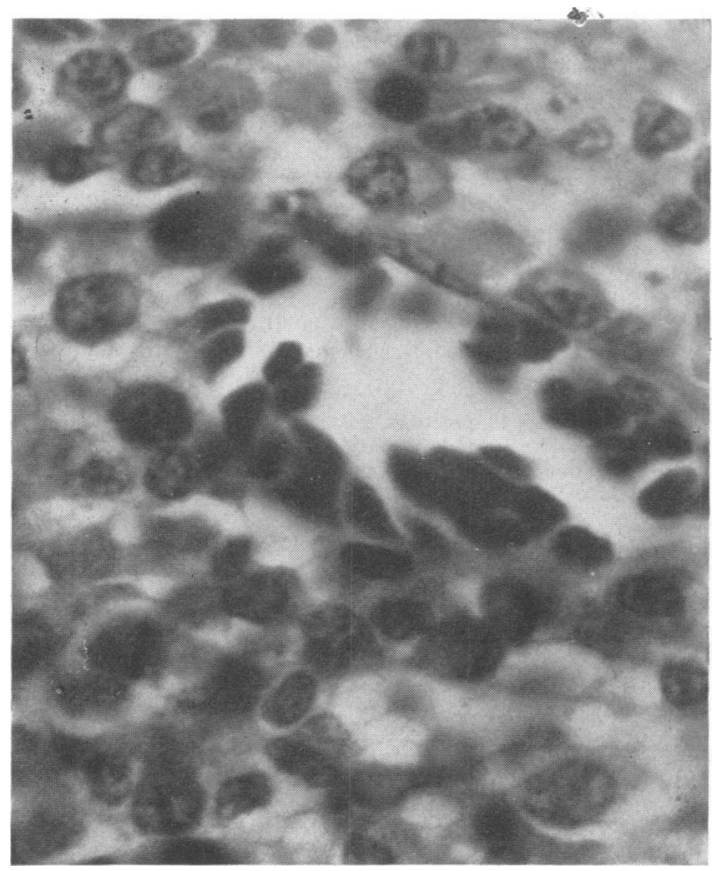

Fig. 5 Dilated capillary vessel in the papillary layer filled partially with erythrocytes and surrounded almost exclusively by plasma cells (section stained with haematoxylin and eosin; $\times 1500$ magnification). inoculated intratesticularly with $0.3 \mathrm{ml}$ of exudate and aspirate from the ulcerated lesions. Ten days later the animal remained asyptomatic; the VDRL test gave negative results but the WR became positive. One month after the inoculation the results of all the serological tests mentioned above, except the TPI test, became positive (the VDRL test at a titre $1: 4$ and the FTA- 200 test at a titre $1: 300$ ). The rabbit died two months after inoculation without clinical signs.

\section{Treatment and course of the illness}

The patient was given 600000 units procaine penicillin daily for three days, then 900000 units daily up to a total dose of $\mathbf{3 0}$ megaunits. The first injection of penicillin was followed by a rise in temperature to $40 \cdot 1^{\circ} \mathrm{C}$, with concomitant chills and headaches. A few days later the foul-smelling exudate diminished, but healing was slow.

\section{Observation after treatment}

Two months after the patient's discharge the result of the VDRL test was positive at a titre 1:32 and that of the FTA- 200 test positive at a titre 1:16000. The patient was not seen again until 21 October 1975. The VDRL result was still strongly positive; the titre of the FTA-200 test, however, had increased to $1: 64000$.

From April to December 1976 the woman remained under observation, but there was no clinical evidence of recurrence. The CSF cell count was normal; the VDRL and FTA results in the CSF were negative; but the serum VDRL still gave positive results at a titre 1:64; and the FTA-2oo test result was positive at a titre 1:1300. In January 1977 she began further treatment with procaine penicillin in a municipal venereological dispensary.

\section{Discussion}

Treatment of the first infection with penicillin was followed by a negative VDRL result one year after the end of the treatment. During the next 26 months the patient had had ample opportunity to acquire a fresh infection, and it seems reasonable to presume the second episode was a reinfection. The course of the reinfection was much more severe, and the signs of malignancy were accentuated by the appearance of ulcerated and even necrotic lesions, resembling the tertiary syphilides; furthermore the general condition of the patient was worse.

The negative results in the search for $T$. pallidum in the exudates and in the aspirate of the ulcerous lesions during reinfection contrasts with the enormous masses of these organisms in the plasma cell 


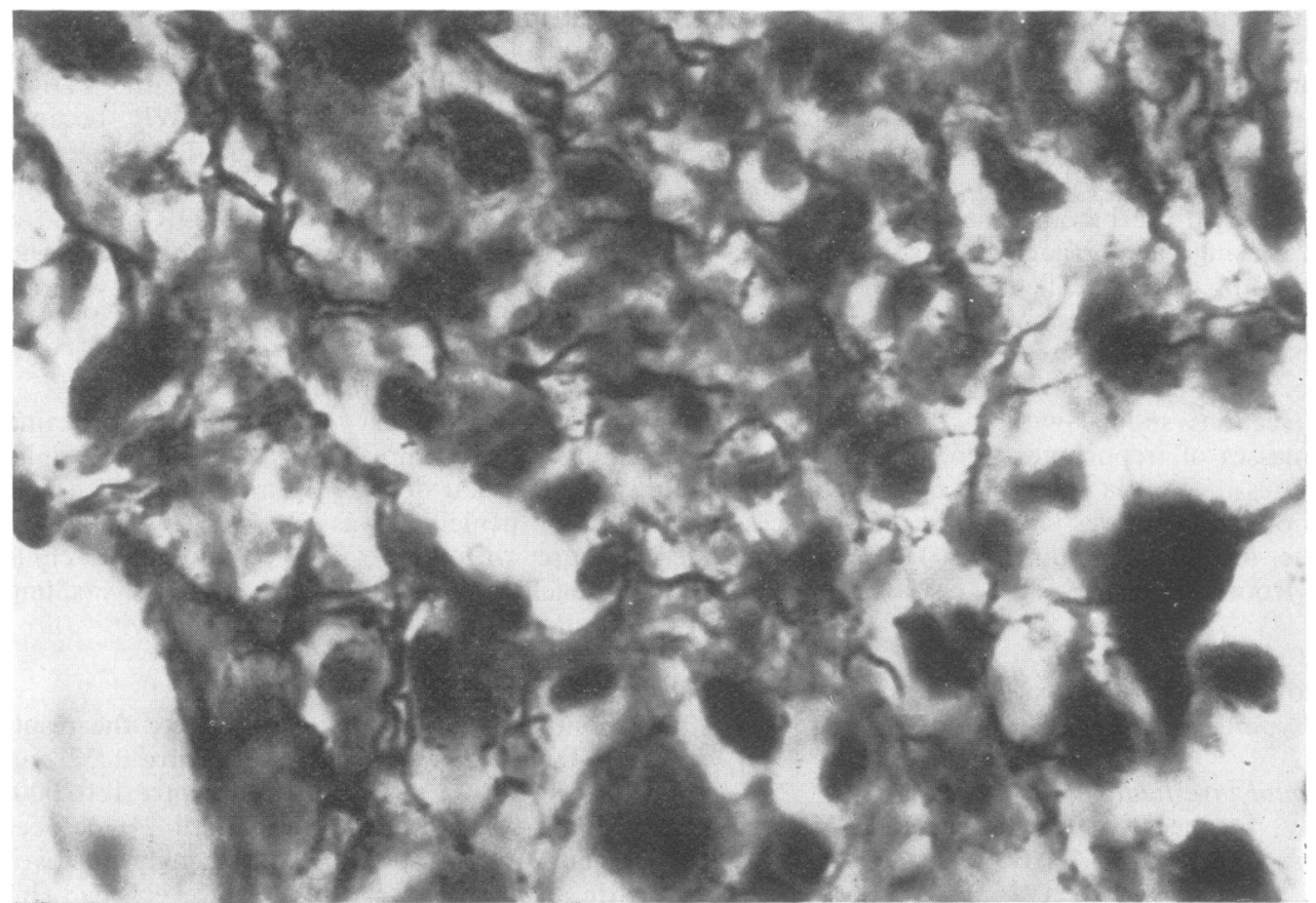

Fig. 6 Enormous masses of T. pallidum within the infiltrate of plasma cells from the margin of an ulcerous lesion (section stained with modified Krajian silver impregnation method; $\times 1500$ magnification).

infiltrates seen in the histopathological section stained with the modified silver impregnation method from the destructive lesions. The absence of the treponemes in the expressed serum may be explained by their deeper localisation.

Although some of the lesions during reinfection resembled tertiary lesions, their histopathological and microbiological features corresponded to the early stage of the disease.

The lack of clinical response in the infected rabbit suggests that the treponemal isolates were not equally virulent. This in turn suggests that the malignant course of the patient's disease reflects the body's response against treponemal infection.

\section{References}

Agache, P., Barale, Th., Bidart De La Noë, A. M., and Bessot, B. (1970). Syphilis maligne précoce après traitement insuffisant par penicilline. Bulletin de la Société française de dermatologie et de syphiligraphie, 77, 356-359.
Buck, C. (1974). Papulo-ulceröses Syphilid-Lues maligna. Ein kasuistischer Beitrag zur klinischen Symptomatik. Hautarzt, 25, $351-353$.

Degos, R., Touraine, R., Collart, P., Daniel, F., and Audebert, G. (1970). Syphilis maligne précoce d'évolution mortelle (avec éxamen anatomique). Bulletin de la Société française de dermatologie et de syphiligraphie, 77, 10-15.

Jarowinskij, B. G., and Cholin, O. Ju. (1973). Słuczaj złokaczestwiennogo syfilisa (Syphilis maligna). Wiestnik Dermatologii $i$ Wenerologii, 9, 88-90.

Laugier, M. P., Hunziker, M. N., and Bezzola, M. A. (1970). Un cas de syphilis maligne précoce. Bulletin de la Société française de dermatologie et de syphiligraphie, 77, 15-16.

Lejman, K., and Starzycki, Z. (1972). Syphilis maligna praecox. A case report. British Journal of Venereal Diseases, 48, 194-199.

Lomyskin, A. I., and Lanne, T. K. (1975). Papulo-bugorkowyj syfilid u bolnogo złokaczestwiennym syfilisom. Wiestnik Dermatologii $i$ Wenerologii, 4, 89-92.

Pariser, H. (1975). Precocious noduloulcerative cutaneous syphilis. Archives of Dermatology, 111, 76-77.

Petrozzi, J. W., Lockshin, N. A., and Berger, B. J. (1974). Malignant syphilis. Severe variant of secondary syphilis. Archives of Dermato$\log y, 109,387-389$.

Sehgal, V. N., and Rege, V. L. (1974). Malignant syphilis and hepatitis. British Journal of Venereal Diseases, 50, 237-238.

Walter, E. K., Smith, J. L., Israel, C. W., and Gager, W. E. (1969). A new modification of the Krajian silver stain for Treponema pallidum. British Journal of Venereal Diseases, 45, 6-9. 